\title{
UNIVERSITY E-READINESS FOR THE DIGITAL TRANSFORMATION: THE CASE OF UNIVERSIDAD NACIONAL DEL SUR
}

\section{PREPARAÇÃO UNIVERSITÁRIO PARA A TRANSFORMAÇÃO DIGITAL: O CASO DA UNIVERSIDAD NACIONAL DEL SUR, ARGENTINA}

PREPARACIÓN UNIVERSITARIA PARA LA TRANSFORMACIÓN DIGITAL: EL CASO DE LA UNIVERSIDAD NACIONAL DEL SUR, ARGENTINA

\section{Marisa A Sanchez}

Doctorate degree in Computer Science from Universidad Nacional del Sur in Bahía Blanca, Argentina. She is currently Associate Professor of graduate and post-graduate courses at Department of Management Sciences at Universidad Nacional del Sur mas@uns.edu.ar http://orcid.org/0000-0002-8291-0491

Editor Científico: José Edson Lara Organização Comitê Científico Double Blind Review pelo SEER/OJS Recebido em 26.12.2019 Aprovado em 27.03.2020

\section{(c) (1) (9)}

Este trabalho foi licenciado com uma Licença Creative Commons - Atribuição - Não Comercial 3.0 Brasil 


\begin{abstract}
This study aims to explain the resources, capabilities and management choices necessary to respond to the new environment for the case of public university institutions. There is little research about responsiveness to the digital transformation in public universities. The methodology is based on literature review and a case study. A Public Agency Strategic Analysis is used to identify relevant issues to conduct the case study. Results show that the organizational processes, talent management and education service models have not been transformed as a result of emergent technologies. The work provides a comprehensive analysis of the capabilities, barriers and the role of the bargaining power of multiple forces affecting the digital transformation of a public sector organization. The article provides specific and actionable recommendations on relevant challenges when public university institutions conduct a digital transformation process.
\end{abstract}

Keywords: Digital transformation; University; Higher education; Digital strategy; Public sector

\title{
Resumo
}

Este estudo tem como objetivo explicar os recursos, capacidades e escolhas de gestão necessárias para responder ao novo ambiente para o caso das instituições universitárias públicas. Há pouca pesquisa sobre capacidade de resposta à transformação digital nas universidades públicas. A metodologia é baseada em revisão de literatura e um estudo de caso. Uma Análise Estratégica da Agência Pública é usada para identificar questões relevantes para conduzir o estudo de caso. Os resultados mostram que os processos organizacionais, gestão de talentos e modelos de serviços de educação não foram transformados como resultado de tecnologias emergentes. $\mathrm{O}$ trabalho fornece uma análise abrangente das capacidades, barreiras e o papel do poder de barganha de múltiplas forças que afetam a transformação digital de uma organização do setor público. Em termos de contribuições práticas, o artigo fornece recomendações específicas e acionáveis sobre os desafios relevantes quando as instituições universitárias públicas realizam um processo de transformação digital.

Palavras-chave: transformação digital; Universidade; Ensino superior; Estratégia digital.

\section{Resumen}

Este estudio tiene como objetivo explicar los recursos, las capacidades y las opciones de gestión necesarias para responder al nuevo entorno de las instituciones universitarias públicas. Hay poca investigación sobre la capacidad de respuesta a la transformación digital en las universidades públicas. La metodología se basa en una revisión de la literatura y un estudio de caso. Un análisis estratégico de la agencia pública se utiliza para identificar cuestiones relevantes para llevar a cabo el estudio de caso. Los resultados muestran que los procesos organizacionales, la gestión del talento y los modelos de servicio educativo no se han transformado como resultado de las tecnologías emergentes. El trabajo proporciona un análisis exhaustivo de las capacidades, barreras y el papel del poder de negociación de múltiples fuerzas que afectan la transformación digital de una organización del sector público. En términos de contribuciones prácticas, el artículo proporciona recomendaciones específicas y viables sobre 
los desafíos relevantes cuando las instituciones universitarias públicas emprenden un proceso de transformación digital.

Palabras clave: transformación digital; Universidad; Enseñanza superior; Estrategia digital

\section{Introduction}

In the evolutionary process of digital transformation now underway, the metaphorical walls and gates that have defined higher education are falling down (Haggans, 2015). Technologies extend free learning to everyone and everywhere. Classrooms need to be adapted to support the hybridization of the learning experience. Academic libraries have evolved from focusing on the management of physical resources and related services to transforming resources and services into digital formats to support teaching, learning and research (Choi \& Rasmussen, 2009). Teece (2017) observes that the digitization of increasing quantities of educational content has the potential to undermine existing delivery models, erase the value of many venerable brands, and enable the rise of new entrants and nimble incumbents.

In the Qingdao Declaration, UNESCO stated that the transformation in education will be achieved through the promotion of digital opportunities and the use of Information and Communication Technology (ICT) to achieve education targets and new sustainable goals. For the case of public universities, technology offers an opportunity to support high public university goals of access, inclusion, equity, and lifelong learning opportunities. However, institutions must adapt their educational and practical theories to adopt emerging technologies and provide answers to new generations of students that have added technology to their daily life. Teece (2017) argues that managing a university is more complex than managing a private for-profit enterprise. There are not only more stakeholders to satisfy but there are also political issues, such as free speech, community involvement, and inclusion, to deal with (Teece, 2017), (Pearce, Wood, \& Wassenaar, 2018). Given the complexity of the university system emerging from the scale of operations, from challenges posed by emerging technologies, and from the public role, the development of responsiveness to the necessary changes in order to include ICT is a demanding goal.

This study aims to explain the resources, capabilities and management choices necessary to respond to the challenges posed by emergent technologies for the case of public higher education institutions (HEIs). Emergent technologies include big data, data analytics, artificial intelligence, Internet of Things (IoT), cloud computing, social networks, mobile. The analysis 
of resources and capabilities is based on the traditional Resource-based view (RBV) theory of the firm and dynamic capabilities (Hansen \& Ferlie, 2014), (Teece, 2007). Considering that any course of action in a public organization environment is shaped by the bargaining power of many different forces (academics, students, government agencies, labor unions), an analysis based on the Public Agency Program Five Forces framework (Vining, 2011) is performed. In (Sánchez \& Zuntini, 2019) the authors analyzed digital readiness for the case of a public agency and relied on a strategic management approach. This work adopts the same approach. In addition, in view of the increasing role of digital platforms in today value creation models, classical references on platforms business models are used to identify relevant issues for the case of HEIs. Based on the analysis based on the aforementioned frameworks and a review of digital transformation in universities, a conceptualization of relevant themes is conceived and constitutes the baseline to conduct a case study. The case is based on a public university and its analysis provides insights into the goal of the paper.

The article is organized as follows. Section 2 provides a literature review of influential strategic management theories and frameworks, and a practice review of digital transformation in HEIs. Section 3 describes the research methodology. Section 4 is devoted to present the results. Finally, a discussion of results and conclusions are described.

\section{Theoretical background}

In the context of this work the conceptualization of "digital transformation" for public sector organizations refers to the adoption of processes and practices to help public organizations provide social value in an increasingly digital world (Sánchez \& Zuntini, 2019). The need for digital transformation involves adapting to how individual citizens, civil society, government agencies, business and other stakeholders use digital technologies. The analysis of the bargaining power of stakeholders, the resources and capabilities, relies on private sector strategic analysis and management. Vining (2016) presents a framework for analyzing the most important forces in a public organization's external environment. The interested reader is referred to the works of Vining (2016), (2011) for a comprehensive theoretical discussion of how public agency strategic analysis differs from firm strategy analysis. 


\subsection{Basic Public Agency Program Five Forces Framework}

In Argentina -unlike for example in France where public policies are crucial for universities, or United States where there is a large influence of the market- strictly internal dynamics linked to different political positions, labor unions, and professional chambers, play a leading role in the university operation dynamics (Pérez Lindo, 2017). A goal of a public agency should be on increasing social efficiency or social value (Vining, 2016). Supplier bargaining power in the public agency context is directly transferable to government programs and the strength of the bargaining power of participants can vary widely depending on their political influence (Vining, 2011). This bargaining power may be treated differently according to the normative goals that characterize the organization. From a stakeholder perspective, strong supplier bargaining power may not be seen negatively because stakeholders are treated as important. For the case of universities in Argentina, labor unions constitute a strong political force.

In the governmental sector there are frequently formal legal or institutional barriers to new entrants (Vining, 2011). University evaluation in Argentina is in charge of an autonomous agency (CONEAU) connected with the Ministry of Education. This agency coordinated and carries out external evaluation of institutions every six years, after internal processes of selfevaluation; it gives accreditation to undergraduate careers considered to involve risk and of public interest; it comments on the consistency and viability of institutional projects, a requirement to set up new institutions (Marquina, 2011). The evaluations are not directly linked to funding, but programs have been created to improve weaknesses highlighted in the agency assessments.

Vining (2011) modifies the concept of customer bargaining power and distinguishes those consuming the service (consumers) and those funding the service (sponsors). Examples of sponsors are the Ministry of Education through its related agencies that define programs, funding and give accreditation to careers. Citizens may be considered as consumers since some consume the service (they also contribute with taxes). They are able to exercise their bargaining power when they chose an educational institution.

Vining (2011) notes the concept of rivalry is conceptually relevant even in a monopoly situation because the degree of contestability is often more important in determining the degree of autonomy than is direct competition. HEIs in Argentina may be considered rivals because they compete for public funds and for students. 


\subsection{Resource-based theory of the firm and Dynamic Capabilities}

According to the RBV theory of the firm the origins of competitive advantage are valuable resources (or competences) that firms possess, which are often intangible assets such as skills or reputation (Penrose, 1959). While public organizations do not aim to control resources, this is still a powerful theory to understand the management in public services (Hansen \& Ferlie, 2014), (Andrews, Beynon, \& McDermott, 2015), (Barney, Ketchen, \& Wright, 2011), (Matthews \& Shulman, 2005). According to Hansen and Ferlie (2014) the concept of dynamic capabilities seems to match current volatile environment in which many public organizations have to adapt rapidly. Ongaro and Ferlie (2019) argue that strategic management models can be usefully applied to improve the understanding of decision-making processes even in jurisdictions where the penetration of New Public Management (NPM) reform has been much lower provided certain conditions. As stated by the authors, most countries in Europe, Asia, Africa or Latin America have only partially, if at all, adopted NPM reforms. In these cases, the conditions to apply strategic management models are agency autonomy and that factors such as stakeholders' expectations may stimulate the adoption of strategic management models, acting as the functional equivalent of the pressures provided by NPM incentivization systems (Ongaro \& Ferlie, 2019). Lynch and Baines (2004) explore some of the assumptions that underpin the RBV in relation to public sector strategy in UK higher education institutions. The profit-maximizing assumption of business can be applied to HEIs as "funds surplus to costs" are retained by the HEIs to finance expansion programs (Lynch \& Baines, 2004). For competitive advantage to be sustainable, the RBV argues that strategic resources in a company must be heterogeneous (e.g. teaching and research teams), possess exante (e.g. investments in new educational areas) and ex-post (e.g. reputation of certain departments) limits to competition, and be imperfectly mobile (e.g. people might be attracted by salaries or research opportunities of other institutions) (Peteraf, 1993).

Teece (2017) presents the dynamic capabilities framework with indications for how it applies in the university context. The framework includes three dynamic capabilities for the implementation of digitized education: sensing, seizing and transforming. Sensing activities begin by assessing the strengths and weaknesses of current course offerings. Then, an understanding of the technological possibilities is required. Small experiments can be run and promising initiatives can be seized on a larger scale. Transformation involves adjusting the resources to support the initiatives (Teece, 2017). 
The literature related with desirable capabilities in public organizations identifies creativity, effectiveness, efficiency, openness, technology savviness, among others (Gil-Garcia, Zhang, \& Puron-Cid, 2016). Transparency and the right to access government information are now internationally regarded as essential to democratic participation, trust in government, prevention of corruption, informed decision-making, accuracy of government information, and provision of information to the public, companies, and journalists, among other essential functions in society (Bertot, Jaeger, \& Grimes, 2010), 2010), (Gil-Garcia, Zhang, \& Puron-Cid, 2016).

Research considering digitally maturing organizations in the private sector is vast and some of its findings should be relevant for the public sector. One of the most comprehensive studies was conducted by the MIT Sloan Management Review and Deloitte (Kane, Palmer, Phillips, Kiron, \& Buckley, 2018). The authors highlight that the most digitally mature organizations are more than four times likely to be developing needed digital leaders than the least digitally mature ones. Digitally maturing companies push decision-making further down into the organization and are more likely to experiment an iterate. The peace of business; culture and mindset; and a flexible, distributed workplace are among the biggest differences between digital and traditional business. Individuals report needing to continually develop their skills or say they get little to no support from their organization to do so (Kane, Palmer, Phillips, Kiron, \& Buckley, 2018).

Another key capability addressed in the literature is data management expertise (Davenport, Barth, \& Bean, 2012), (Klievink, Romijn, Cunningham, \& Bruijn, 2017), (McAfee \& Brynjolfsson, 2012), (McAfee \& Brynjolfsson, 2017). Organizations gather an increasing amount of data and the challenge is to transform this data into actionable knowledge.

\subsection{Review of digital transformation in higher education}

Intelligent campus (i-campus) refers to a new paradigm of thinking pertaining to a holistic intelligent campus environment which encompasses at least, but not limited to, several themes of campus intelligence, such as holistic e-learning, social networking and communications for work collaboration, green and ICT sustainability with intelligent sensor management systems, protective and preventive health care, smart building management with 
automated security control and surveillance, and visible campus governance and reporting (Kwok, 2015).

Haggans (2015) describes the implications of digital transformation on higher education related with (a) the physical campus (e.g. time in class need not to be face-to-face), (b) learning (e.g. learning environments need to be adapted to support the hybridization of experience; rooms bigger, flatter, faster and with access to robust bandwidth), (c) libraries (on-campus space can be renovated and reconfigured for use by the campus community), and (d) offices (the private and fixed office arrangement may result dysfunctional).

The Internet of Things has the potential to contribute for the classroom to become an "open" space, where the physical limitations will not be relevant to the interpretation of the outside world, which can be monitored, analyzed and studied in real time, creating hypersituation provisions (Moreira, Magalhaes, Ramos, \& Vairinhos, 2018).

Uskov et al. (2017) provide a review of teaching strategies and learning models that strongly support smart pedagogy (for example, adaptive teaching, game-based learning, ebooks pedagogy, MOOCs, learning analytics, collaborative learning, flipped classroom, robotics-based learning). Traditional HEIs are being disrupted by massive open online courses (MOOCs) organizations such as Coursera, Udacity, edX. To the extent that MOOCs are envisaged to offer flexibility to course delivery, render affordable access to online higher education in comparison with mainstream traditional education and enable fast-track completion of courses at low cost for anyone interested in learning, they qualify as disruptive technologies that can potentially transform higher educational landscape (Rambe \& Moeti, 2017), (Rambe \& Moeti, 2017). Teece (2017) observes that although personal interaction with professors, assistants, and other students adds value to campus, virtual reality and the use of artificial intelligence to personalize instruction could potentially erode even that distinction. Koller (one of the founders of Coursera) mentions that by collecting an unprecedented amount of data about how students are learning, and analyzing it in real time, educators could realize their dreams of personalized education at a large scale (Leber, 2012). The literature on platforms ecosystems highlights the role of MOOCs (Parker, Van Alstyne, \& Choudary, 2016). The spread and increasing popularity of teaching and learning ecosystems will have an enormous impact on public school systems, private schools, and traditional universities (Parker, Van Alstyne, \& Choudary, 2016). These models are based on platforms that are the digital expressions of ecosystems (Stacey, 1995), (Iansiti \& Levien, 2004). Relevant themes for public universities arising from this body of knowledge are defining a strategy to foster ecosystem 
value, on-demand orientation, encouraging interactions, regulations, how incumbents can retain competitive advantage.

Another expression of networking activity is described by Machovec (2017) who analyses formal collaboration among libraries through consortia. The author provides some examples in which modern library consortia may collaborate: shared e-resource licensing, ebooks, shared library service platforms, among others.

Some of the challenges to the traditional ways of thinking on campus include: the use of mobile devices together with the high speed network may be a source of distractions for students (Kwok, 2015); teachers experience a changing role from an information provider to a learning facilitator; teachers might not have enough time for training; library professionals require experience with technology associated with library information systems (Raju, 2014); data analytics literacy to support IoT-based solutions (Meyers, Niech, \& Eggers, 2015); security and privacy of data related to students; reliable wi-fi connections, organization's ability to build on IoT setup, and cost (Moreira, Magalhaes, Ramos, \& Vairinhos, 2018), (Gul, et al., 2017); policy makers and regulatory bodies participation in e-learning programs (Rohayani, Kurniabudi, \& Sharipuddin, 2015).

\section{Methodology}

The case research (Yin, 1989) methodology is used for this study. The research questions are "how" questions that seek to understand barriers and required conditions to generate value from technology. Based on the research question, the requirements for the case selection were: the case organization must be public; and the service delivered and/or the processes should exhibit a quite good level of digitalization.

The research is structured in four phases. First, the identification of a set of themes and dimensions that formed the theoretical lens based on a literature review. This conceptualization is the baseline to define a questionnaire to guide individual in-deep interviews (second phase). The third phase corresponds to interviews and a documentary revision of institutional strategic plans, regulations, and annual reports. The use of interviews and documentary data supported the triangulation of data sources.

Experienced participants were selected. Time was given to the interviewees to discuss the proposed topics and add all the information that they consider relevant. The average duration of interviews was of 80 minutes, they took place at the work-place. The preparation of 
the interview included an explanation of the purpose and structure of the interview, confidentiality terms, and the method of recording (taking notes). Data analysis was then carried out.

\section{Results}

Based on the analysis of the state of the art and practice (summarized in section 2), some themes the significance of digital transformation within higher education are derived. The aim is to highlight relevant conditions, resources and capabilities to define the questionnaire that will guide the interviews (see Table 1).

Table 1. Emerging dimensions

\begin{tabular}{|c|c|}
\hline Emerging dimensions & Related questions \\
\hline \multicolumn{2}{|l|}{ Strategy definition and competitive strength } \\
\hline Foster ecosystem value and collaboration & $1,4,10$ \\
\hline i-campus & 2,11 \\
\hline On-demand orientation & $3,5,11$ \\
\hline Strength of new entrants and rivalry. & $5,11,16$ \\
\hline $\begin{array}{l}\text { Political influence (Ministry of Education, labor unions), regulations to } \\
\text { implement e-learning. }\end{array}$ & $4,5,8,16$ \\
\hline \multicolumn{2}{|l|}{ Resources and dynamic capabilities } \\
\hline $\begin{array}{l}\text { Creativity, entrepreneurialism, openness, resiliency, technology savviness, } \\
\text { integration, innovation, data talent, collaborative culture, agile, transparency. }\end{array}$ & $\begin{array}{l}1,2,8,11,12,13 \\
14,15,16\end{array}$ \\
\hline Leadership and organizational culture & $6,7,8,9,10,16$ \\
\hline
\end{tabular}

Source: Own elaboration.

In section 2 it was mentioned that two conditions are required to apply a strategic management model to analyze non-NPM administrations. Starting with the requirement of autonomy, in the case of UNS, conditions of autonomy are introduced since the 1918 University Reform, a model based on the autonomy of institutions vis à vis the national government with regard to political, academics and economic matters (Marquina, 2011). The second condition refers to stakeholders' expectations that perform as the functional equivalent of the incentivization systems found in NPM settings (Ongaro \& Ferlie, 2019). In the case of UNS, as it will be further developed in the following sections, there are powerful stakeholders such as academics, administrative staff, and students that are quite influential in shaping the strategy and future of the organization. 
The remaining of this section compiles the results of the interviews. The interviews were conducted with a small number of participants to explore their perspectives on resources, capabilities and management choices necessary to respond to the new environment for the case of UNS. The interview is semi-structured since all respondents answered a set of predefined questions but additional questions were posed to clarify certain issues. Participants belong from all the organizational categories and there are faculties from both social and hard sciences: local authorities (3), faculties (4), administrative staff (2), professional staff (4), and technical staff (1). All participants observed that there are new authorities at the university. Hence, answers are based on new authorities.

\subsection{Context and organization description}

Created in 1956, Universidad Nacional del Sur is one of the most important institutions of higher education, research and extension in the country. The university is organized in departments (17) and research centers (9). The government of the university is constituted by the Rector and the Superior Council. The Rector is elected by the University Assemble -a representative organ of the academics, administrative staff, and students- and last four years in his function. The Superior Council is composed of the Rector, the Deans of the sixteen Departments and representatives for each of the academic, administrative staff and student bodies. Each Department has a government composed of the Dean and a Department Council. There are eight secretariats: General Coordination; Academic (includes Academic Coordination, Management, Degrees, Pedagogy Consultancy and Main Library offices); General (includes Personnel, Economy and Finances, Information Systems, Telecommunications, Infrastructure and Printing offices); University Welfare (includes Students Affairs, Health and Sport offices); Science and Technology; Culture and University Extension (includes University Press, Communications, Media, and Memorial Archive); Postgraduate Studies and Distance Education; and Planning (includes Internationalization and Institutional Information offices). In addition, a kindergarten, a primary school and four junior high schools are dependent on the university.

There are 23,619, undergraduate students, 1,761 postgraduate students, 3,099 academic staff, 60 undergraduate careers, 64 postgraduate careers, and 581 administrative and technical staff (Universidad Nacional del Sur, 2018). 
The results derived from the interviews are presented in next sections. In order to make it clear which questions had given raise to what data, information, views or insights, we detail results in line with questions. It worth noting that even though most questions are formulated using a Likert scale, this is only for the means to ease the dialogue. Questions were used as a trigger to discuss a topic.

\subsection{Strategy and competitive strength}

Most respondents agree on that the value proposition depends on new forms of collaboration with stakeholders. One respondent (administrative staff) observed that even though the discourse is one of collaboration, sometimes "political issues" are stronger. In all cases, respondents referred to "collaboration" but did not grasp the idea of "new forms of collaboration that emerge from digital transformation".

All respondents coincided with that learning content management tools are part of the strategy and highlighted the implementation and maintenance of Moodle platform. The adoption of Moodle is optional (there are 1500 grade and post-graduate courses registered). Also, most agreed on that process transformation is also part of the strategy. Some observed that this is highly dependent on the area: those that comply with IRAM ISO 9001:2015 quality certifications have a proactive attitude towards process improvement (Degrees office, Personnel office and Main Library). Other areas such as Finance and Economy took a long time to update the software as suggested by the Ministry of Education. Process transformation at the university follows the SIU project headed by the national Ministry of Education (SIU is the Spanish abbreviation for University Information Systems). Since 1996, SIU develops information systems required by different areas at a university (Consejo Interuniversitario Nacional, 2019). Today, all public and private universities use at least one module of SIU platform. A barrier to process transformation is normative update (for example, the use of digital firm was supported by authorities and 50 tokens were bought, but there is not a normative that regulates the procedure of who is authorized to use the digital firm and for what).

Regarding e-books pedagogy the opinions diverged and this depended on the participant's working area. There are some isolated initiatives that do not belong from an institutionalized strategy. The university offers some online courses through the Postgraduate and Continuing Education Secretary, but they are not supported with a massive platform. Even though there is a clear concern of authorities on online education there is not a strategic formulation defining the necessary changes for its implementation. Some respondents observed 
that the major barrier is faculties' lack of the required capabilities to implement an online course. Learning data analytics is not part of the strategy and is restricted to (a) Moodle reports (few faculties systematically analyze these data), (b) students course survey (optional), and (c) university entrance exams' statistics.

Respondents explained that the nurturing of faculty members' competencies in smart technology is not part of the strategy (Universidad Nacional del Sur, 2013), although there are Moodle management courses and different initiatives headed by some academic departments.

Concerning the improvement of university infrastructure with smart technology, respondents mentioned that there is not an initiative relating to "smart" technologies. There are always funds to acquire the necessary infrastructure for the operation of administrative and academic systems. There is a special program for university infrastructure update approved and in execution that is funded by the Ministry of Education. Intelligent technology is available in the computer centre for security purposes.

Data driven decision making is not stated in the strategy. There is a data-warehouse fed with data coming from transactional systems (finance, personnel, academic), however, this is only accessible by authorities and top level administrative staff. Most respondents revealed the perception that politics comes first concerning important decisions. There is decision that fully relies on data: the forecast of departments' annual budget. The computation takes into account the type of courses provided (if they require special supplies), the number of students and faculties, and the historical budget in the last three years.

Most respondents considered the organization moderately knows students needs. Examples of data sources are course surveys, web-surveys available at quality certified areas (Universidad Nacional del Sur, 2019a), (Universidad Nacional del Sur, 2019b), (Universidad Nacional del Sur, 2019c), tutorship programs (Universidad Nacional del Sur, 2019d), EmpleoUNS platform (organizations publish job offers and registered students and graduates upload their curriculum vitae and receive alerts) (Universidad Nacional del Sur, 2019e), and students' proposals to department's councils. However, the fact that these data is registered it does not mean that it is analyzed to support decision-making.

When asked about who has the responsibility to define the digital strategy, interviewees selected the rector, all general secretaries, and academic departments. Some included the Superior Council because it can approve or modify any proposal. Others included the Ministry of Education since it defines national research and academics policies and hence which projects 
will receive funding. The areas responsible of information systems and technological infrastructure do not participate in the digital strategy definition. Authorities seek for their advice after an initiative has been approved. There is not a defined role similar to Chief Digital Information Officer. In other national universities the technology authorities are at the secretary level in the organizational chart (Universidad Nacional de San Luis, 2019).

Regarding drivers related to ICT initiatives, the driver mentioned with more frequency was to comply with public administration process. Other drivers are digital maturity of other government agencies (the Federal Tax Agency requires that the university integrates the salaries calculation modules with some forms to compute income tax retentions), regulations, efficiency (as a consequence of students' complaints about time to fulfill a transaction), Ministry of Education (through the Secretary of University Policies that distributes national universities' budget and SIU project), students' demands (the Moodle platform was requested by students). A respondent observed there is a lack of strong demand from the public administration (at the ministerial level) to define a strategy, goals, and a later control of the fulfillment of these goals.

\subsection{Resources and capabilities}

Most respondents agree on that the university is increasingly pushing decision-making authority down into lower levels of the organization. Decentralization only applies to academic decisions since each department has different needs inherent to academic disciplines. Departmental structure affects decision making. Some respondents observed a positive effect of centralization since it nurtures an institutional coherence and information systems management is more efficient. A faculty structure would demand the same systems to be deployed for each academic unit. Another benefit is that a consensus should be reached in decision making -although sometimes when consensus is not obtained no decision can be made. On the other hand, departmental autonomy allowed some units to be more efficient than others and they headed initiatives related with paperless process, virtual postgraduate thesis defense. One respondent strongly disagreed on that the university is increasingly pushing decisionmaking authority down into lower levels of the organization and mentioned that only operative work is being delegated to departments.

Interviewees said that the academic unit where they are working develops future leaders by means of training, workplace environment and on-the-job learning. Specific programs regarding leadership are not given. Many reported that there is not a clear or transparent 
communication of the criteria regarding promotions. A respondent observed that there are few specific training programs for administrative staff; they are not communicated with time enough to schedule the absence of employees or plan who would benefit more considering the topic.

Respondents considered that all stakeholders inhibit change more than they facilitate it except for authorities and technical staff. Authorities supported digital projects such digital certification of degrees, digital signature and virtual learning. One respondent observed that $93 \%$ of the annual budget is allocated to pay salaries, and hence with the remaining $7 \%$, authorities do not have enough resources to implement new projects. Faculties' resistance depends on age since older ones are less open to changes (this was evident when the academic system to register students' grades was updated, and in the adoption of Moodle platform). Regarding commissions the response depends on the situation: for example, sometimes commissions promote change and propose new and better procedures. However, if there is a conflict of personal interests, then commissions have delays to resolve problems. Regarding students, they show an open attitude towards change but they resist if the change means more responsibility from their part. Some respondents perceived administrative staff as resistant to change, however another respondent observed that an adequate change management is not instrumented when process are redesigned and new information systems are deployed. Some respondents agreed on that the attitude towards change depends on the area but in general an increasing positive attitude is observed. Regarding labor unions, some respondents preferred not to respond since they did not have enough information. Others believe that they do not show interest on the university benefits but they only favor decisions that support political clientelism.

Regarding what the interviewee would like leaders to have more of to help the organization navigate digital trends, the following attributes were selected (the more frequently mentioned are first in the list): collaboration, direction, innovation, execution, organizational judgment and influence.

When asked about the organization attitude towards seeking external advice, there was an agreement on that when there is a problem for which local expertise is not available, the university looks for external consultation (for example, IRAM quality certification and competency-based learning training). The university has fiscal autonomy to do that.

Respondents consider that the organization does not monitor students' and other stakeholders' needs; and it is not experimenting in integrating digital technologies. All participants agreed on that (a) the institution is working on how education is delivered; (b) 
social networks analysis software tools are not used; (c) and there is a lack of a data analytics capability that would allow the discovering of insights from data. Regarding the organization ability to respond to threats and opportunities better than other education organizations, two main issues were exposed. On the one hand, the university is old and this provides well defined procedures, rules, and an organized administration. So, it is feasible that in the long run the university can sustain an initiative. On the other hand, the organization is not agile and is not prepared to compete with services like online education.

Regarding data management, the organization is able to integrate internal data from multiple sources. Data from transactional systems feeds a data-warehouse (10 years of historic data) that is open only to authorities. Senior officials are far from regularly considering the opportunities that data analytics offers. External data or unstructured data is not systematically processed. Some faculties did not know about the existence of the organizational datawarehouse that integrates transactional data. In 2007, the Institutional Information Office was established and one of its functions is to create reports required by authorities. However, its personnel do not accredit data science degrees.

During the interview open data availability was discussed. All respondents mentioned that open data is not accessible. Some data is accessible only to registered users using login and password but only authorities have the credentials to register. Those participants with access to this site, rated as very good the quality, quantity, reliability, update and data format, and they reported that authorities, the media and other government agencies are those who request data more frequently. Two participants reported that they use open data at least once a week, and another two twice a year (2).

\subsection{Barriers to adopt digital technologies}

Interviewees were provided with a list of 15 possible barriers and were asked to select (at most) three. The following barriers were selected (the more frequently mentioned are first in the list): "Lack of organizational strategy", "Multiple priorities that compete", "Insufficient resources", "Lack of leadership", "Faculty members' competence, experience and attitudes towards e-learning", "Lack of organizational agility", "Satisfaction with status quo", "Changing role from an information provider to a learning facilitator (professors)", and "Employees' lack of ability to use digital technologies". One participant observed the lack of culture of taking risks and political interests hinder the definition of a clear vision about digital initiatives. 


\subsection{Organizational Performance}

In order to evaluate the impact of ICT initiatives an overall assessment of results was discussed. In more or less extent most respondents agreed on that little performance improvement is observed in the last two years. There is an improvement in processes and procedures standardization in areas that comply with quality certifications. The data exchange with other public agencies increased like the Ministry of Education and the Federal Tax Agency. Regarding systems reliability, backup procedures have improved in the last two years One participant mentioned that as a consequence of the high inflation rate, some budgets (in national coin) allocated to buy equipment (outside the country) were not executed.

\section{Discussion}

One of the most relevant findings is that the areas responsible of information systems and technological infrastructure do not participate in the digital strategy definition. These areas report to the General Secretary and there is not a defined role similar to Chief Digital Information Officer (CDIO). This reveals a perception of Information Technology only as a means to support functions but it is far from grasping the potential of technology to redefine a value proposition. Hence, the first notion is the inability of the institution itself to define processes of digital transformation. In spite of this, regulations and standards defined by the Ministry of Education, international technological trends, the emergence of agile rivals with value propositions on online education, departments' autonomy that allows individual initiatives to prosper, contributes to digital transformation. Slowly, changes become part of many institutional projects.

Another fact that emerged from interviews is that participants emphasize that digital transformation is not part of the organizational strategy and the absence of a digital leader.

Regarding agility, the organization is not agile and is not prepared to compete with services like online education. On the other hand, the university is old and this provides well defined procedures, rules, and an organized administration. So, it is feasible that in the long run the university can sustain an initiative. Some respondents observed a positive effect of centralization since information technology management is more efficient.

Another recurring topic is the perception that decision making seems to be more influenced by political interests rather by arguments funded on data or performance indicators. 
The university pursues the promotion of the benefits of its actions implemented through university extension. And this reveals the strong commitment to transfer to the community the funds received as a public organization. On the other hand, all participants observed the absence of open data regarding academic and economic themes contributing to the detriment of transparency.

In general, participants reflected about digitization of the organization but nobody described projects based on emerging technologies. Even cloud solutions whose benefits are widely recognized are not institutionalized. Critical systems, data and network work are not in the cloud. Based on participants' views and documentary analysis, the institution does not realize the transformative benefits of the cloud through enabling adoption and providing common services.

\section{Conclusions}

Studies related to organizational readiness for the digital transformation stress the importance of a clearly defined strategy and leadership. Although these aspects emerged as a result of this case study, the complexity of the organization was also evident. Such complexity is given, by the public nature of the organization that creates a commitment with social goals and technology transfer; the need of setting goals through consensus and the bargaining power of multiple actors: academics, administrative staff, labor unions, students, and community. In addition, changes must be backed by regulations, and considering that the need for change is always ahead of regulations, the capability to respond to opportunities is limited. All these issues urge to pose an interesting question: how to apply emergent technologies across the organization in a meaningful way. The absence of a CDIO in the organizational structure makes more difficult to answer the question. A CDIO knows emergent technologies and can help to find a problem they can be applied to.

Even so, all sustainable transformation process must be grounded in an orderly and solid organization that helps sustain any initiative. The departmental structure centralizes decisions and this also slows down changes, but on the other hand provides departmental autonomy that some leverage to develop initiatives with greater agility.

The general concern with the absence of digital leaders hinders digital maturity and this may result in lost opportunities and inefficiencies. Failing to adopt emergent technologies can put the organization at risk of not achieving stakeholders' expectations and wasting of public budget. 
To summarize, there is an opportunity to reframe public university challenges through new technologies. Inspired in Teece's (2017) capabilities framework, the process may involve three phases of sensing (monitor the environment, identifying problems, opportunities, understanding the market), seizing (design of new business models) and transforming.

\section{References}

Andrews, R., Beynon, M., \& McDermott, A. (2015). Organizational Capability in the Public Sector: a Configurational Approach. Journal of Public Administration Research and Theory Advance.

Barney, J., Ketchen, D., \& Wright, M. (2011). The Future of Resource-based Theory: Revitalization or Decline? Journal of Management, 37(5), 1299-1315.

Bertot, J., Jaeger, P., \& Grimes, J. (2010). Using ITCs to create a culture of transparencey: Egovernment and social media as apenness and anti-corruption tools for societies. Government Information Quarterly, 27(3), 264-271.

Choi, Y., \& Rasmussen, E. (2009). What qualifications and skills are important for digital librarian positions in academic libraries? A job advertisement analysis. The Journal of Academic Librarianship, 35(5), 457-467.

Consejo Interuniversitario Nacional. (2019). SIU. Retrieved March 5, 2019, from Sistema de Información Universitaria: https://www.siu.edu.ar/

Davenport, T., Barth, P., \& Bean, R. (2012). How "Big Data" Is Different. MIT Sloan Management Review, 22-24.

Gil-Garcia, J., Zhang, J., \& Puron-Cid, G. (2016). Conceptualizing smartness in government: an integrative and multi-dimensional view. Government Information Quarterly, 33, 524534.

Gul, S., Asif, M., Ahmad, S., Yasir, M., Majid, M., \& Malik, M. (2017). A Survey on Role of Internet of Things in Education. International Journal of Computer Science and Network Security, 17(5), 159-167.

Haggans, M. (2015). The future of the American campus. On the Horizon, 23(1), 25-32.

Hansen, J., \& Ferlie, E. (2014). Applying Strategic Management Theories in Public Sector Organizations: Developing a Typology. Public Management Review, 18(1), 1-19.

Iansiti, M., \& Levien, R. (2004). The keystone advantage: what the new dynamics of business ecosytems mean for strategy, innovation and sustainability. Boston: Harvard BusinessSchool Press.

Kane, G., Palmer, D., Phillips, A., Kiron, D., \& Buckley, N. (2018, June). Coming of Age Digitally. Research Report. MIT Sloan Management Review and Deloitte Insights. Boston: MIT Sloan Management Review. Retrieved from Coming of Age Digitally: http://sloanreview.mit.edu/digital2018

Klievink, B., Romijn, B., Cunningham, S., \& Bruijn, H. (2017). Big data in the public sector: Uncertainties and readiness. Information Systems Frontiers, 19, 267-283.

Kwok, L.-f. (2015). A vision for the development of i-campus. Smart Learning Environments, 2(2), 1-12.

Leber, J. (2012). The Technology of Massive Open Online Courses. MIT Technology Review, $116(1), 63-64$. 
Lynch, R., \& Baines, P. (2004). Strategy development in UK higher education: towards resource-based competitive advantages. Journal of Higher Education Policy and Management, 26(2), 171-187.

Machovec, G. (2017). Trends in Higher Education and Library Consortia. Journal of Library Administration, 57(5), 577-584.

Marquina, M. (2011). Higher education reform in Argentina in the 1990s:Paradoxes of government intervention. Higher Education Forum, 8(3), 93-104.

Matthews, J., \& Shulman, A. (2005). Competitive advantage in Public sector organizations: Explaining the public goog/sustainable competitive advantage paradox. Journal of Business Research, 58(2), 232-240.

McAfee, A., \& Brynjolfsson, E. (2012, October). Big Data: The Management Revolution. Harvard Business Review, 10, 60-79.

McAfee, A., \& Brynjolfsson, E. (2017). Machine, Platform, Crowd. Harnessing our digital future. New York: W. W. Norton \& Company Ltd.

Meyers, M., Niech, C., \& Eggers, W. (2015). Anticipate, sense, and respond. Connected government and the Internet of Things. Deloitte University Press.

Moreira, F., Magalhaes, A., Ramos, F., \& Vairinhos, M. (2018). The Power of the Internet of Things in Education: An Overview of Current Status and Potential. In Ó. Mealha, M. Divitini, \& M. Rehm (Eds.), Citizen, Territory and Technologies: Smart Learning Contexts and Practices. SLERD 2017. Smart Innovation, Systems and Technologies (Vol. 80, pp. 5163). Cham: Springer.

Ongaro, E., \& Ferlie, E. (2019). Exploring Strategy-Making in 'Non-New Public Management' Public Services Settings: The Case of European Union Agencies. Administrative Sciences, 9(23), 1-23.

Parker, G., Van Alstyne, M., \& Choudary, S. (2016). Platform Revolution. How networked markets are transforming the economy and how to make them work for you. New York: W. W. Norton \& Company.

Pearce, C., Wood, B., \& Wassenaar, C. (2018). The Future of Leadership in Public Universities: Is Shared Leadership the Answer? Public Administration Review, 78(4), 640-644.

Penrose, E. (1959). The Theory of the Growth of the Firm. New York: Wiley.

Pérez Lindo, A. (2017). La Educación Superior Argentina (1983-2015). Diagnóstico y Prospectiva. Buenos Aires: Eudeba.

Peteraf, M. (1993). The cornerstones of competitive advantage: a resource-based view. Strategic Management Journal, 14, 179-191.

Raju, J. (2014). Knowledge and skills for the digital era academic library. The Journal of Academic Librarianship, 40, 163-170.

Rambe, P., \& Moeti, M. (2017). Disrupting and democratising higher education provision or entrenching academic elitism: Towards a model of MOOCs adoption at african universities. Educational Technology Research and Development, 65(3), 631-651.

Rohayani, H., Kurniabudi, \& Sharipuddin. (2015). A Literature Review: Readiness Factors to measuring e-Learning Readiness in Higher Education. Procedia Computer Science, 59, 230234.

Sánchez, M., \& Zuntini, J. (2019). Digital Readiness in Government: the Case of Bahía Blanca Municipal Government. International Journal of Electronic Governance, 11(2), 155-181.

Stacey, R. (1995). The science of complexity: an alternative perspective for strategic change processes. Strategic Management Journal, 16(6), 477-495.

Teece, D. (2007). Explicating dynamic capabilities: the nature and microfoundations of (sustainable) enterprise performance. Strategic Management Journal, 28(13), 1319-1350. 
Teece, D. (2017). Managing the university: Why "organized anarchy" is unacceptable in the age of massive open online courses. Strategic Organization, 1-11.

Universidad Nacional de San Luis. (2019). Universidad Nacional de San Luis. Retrieved April 29, 2019, from Secretarías y Rectorado UNSL: http://www.unsl.edu.ar/index.php/menu/institucional/secretarias

Universidad Nacional del Sur. (2013). Plan Estratégico de la Universidad Nacional del Sur 2011-2016-2026. Bahía Blanca: Editorial de la Universidad Nacional del Sur.

Universidad Nacional del Sur. (2018). Dirección de Información Institucional. Retrieved May 15, 2019, from Anuarios: http://www.uns.edu.ar/contenidos/411/652\#anuarios

Universidad Nacional del Sur. (2019a). Universidad Nacional del Sur. Retrieved April 29, 2019, from Dirección de Títulos y Egresados: http://www.uns.edu.ar/contenidos/442/398\#inicio

Universidad Nacional del Sur. (2019b). Universidad Nacional del Sur. Retrieved April 29, 2019, from Dirección General de Personal: http://www.uns.edu.ar/contenidos/112/536\#inicio

Universidad Nacional del Sur. (2019c). Universidad Nacional del Sur. Retrieved April 8, 2019, from Biblioteca Central de la Universidad Nacional del Sur: http://bc.uns.edu.ar/

Universidad Nacional del Sur. (2019d). Universidad Nacional del Sur. Retrieved April 29, 2019, from Asesoría Pedagógica. Tutorías: http://www.uns.edu.ar/contenidos/407/150\#tutorias

Universidad Nacional del Sur. (2019e). EmpleoUNS. Retrieved March 5, 2019, from http://empleo.uns.edu.ar

Uskov, V., Bakken, J., \& Penumatsa, A. (2017). Smart Pedagogy for Smart Universities. In V. Uskov, R. Howlett, \& L. Jain (Eds.), Smart Education and e-Learning 2017 (Vol. 75, pp. 316). Cham: Springer International Publishing AG.

Vining, A. (2011). Public Agency External Analysis Using a Modified "Five Forces" Framework. International Public Management Journal, 14(1), 63-105.

Vining, A. (2016). What is Public Agency Strategic Analysis (PASA) and how does it Differ from Public Policy Analysis and Firm Strategy Analysis? Administrative Science, 6(19), 131.

Yin, R. (1989). Case Study Research. Design and Methods. Los Angeles: SAGE Publications.

\section{Appendix. Questions used to guide the interviews}

\section{$\underline{\text { Strategy definition }}$}

1. To what extent your value proposition depends on new ways of collaboration with stakeholders?

2. To what extent do you agree that the following are part of your organization's strategy?

(E-books pedagogy. Learning content management tools. Massive open online courses. Learning analytics. Nurturing faculty members' competencies in smart technology. Improving university infrastructure of smart technology. Data driven decision-making. Processes transformation. Intelligent environments).

3. To what extent the organization knows students' needs? 
4. Who has the responsibility to define the digital strategy?

5. Which are the drivers to define an IT initiative?

\section{$\underline{\text { Resources and dynamic capabilities }}$}

6. To what extent do you agree with the following:

- The university is increasingly pushing decision-making authority down into lower levels of the organization.

- The departmental structure affects decision-making.

7. How is your area (department, administrative unit) developing future leaders:

8. How would you describe members' orientation toward change within the organization?

9. What would you like your leaders to have more of to help your organization navigate digital trends (select up to 3 )

- $\quad$ Direction: Providing vision and purpose for digital.

- Innovation: Creating the conditions for people to experiment.

- $\quad$ Execution: Empowering people to think differently.

- $\quad$ Collaboration: Getting people to collaborate across boundaries.

- $\quad$ Building talent: Supporting continuous self-development.

- $\quad$ Inspirational leadership: Getting people to follow you.

- $\quad$ Business judgment: Making decisions in an uncertain context.

- Influence: Persuading and influencing stakeholders.

10. In your opinion, do the organization seeks for external expert advice?

11. In your opinion, your organization ...

- Monitors students and other stakeholders needs.

- Is experimenting in integrating digital technologies (social networks, mobile, analytics and cloud computing).

- Is able to respond to threats and opportunities better than other education organizations.

- $\quad$ Redefined how a basic service is provided.

12. In my organization ...

- $\quad$ Our senior officials regularly consider the opportunities that data analytics might bring to public good.

- We integrate data from multiple internal sources into a data warehouse for easy access.

- We integrate external data with internal to facilitate high-value analysis of our business environment.

- We identify internal opportunities for big data and analytics by evaluating our processes, strategies, and students' needs.

- We have explored or adopted tools to process unstructured data such as text, video, or images.

- Our data scientists, quantitative analysts, and data management professionals operate effectively in teams to address data analytics projects.

13. How would you qualify open data publication?

14. Who requests open data more frequently?

15. Do you utilize open data in your work? 
Barriers to adopt digital technologies

16. Which barriers are limiting your organization to adopt or develop digital technologies?

\section{$\underline{\text { Performance }}$}

17. To what extent your organization's performance has improved in the last two years?

- Reduction of time to solve a problem.

- Processes and procedures standardization.

- Reduction of materials and supplies.

- Use of digital signature.

- Data exchange with other public agencies.

- Systems reliability (e.g. fraud detection, loss of information).

- New electronic services.

- Budget execution. 